\title{
Plasma histamine concentration during propranolol induced bronchoconstriction
}

\author{
PW IND, PJ BARNES, MJ BROWN, CT DOLLERY \\ From the Department of Clinical Pharmacology, Royal Postgraduate Medical School, London
}

ABSTRACT The mechanism of propranolol induced bronchoconstriction in asthma is uncertain, as airway $\beta$ adrenoceptors are not innervated by sympathetic nerves and circulating adrenaline concentrations are not raised. Propranolol $10 \mathrm{mg}$ was infused over 27 minutes in 14 subjects with mild asthma. Peak expiratory flow (PEF) decreased by $80-2351 / \mathrm{min}$ (17-51\% of baseline) in nine subjects, who were called "responders," and by less than $50 \mathrm{l} / \mathrm{min}$ (12\% of baseline) in five "nonresponders." These two groups did not differ in baseline ventilatory function or in any clinical characteristic. In "responders" mean PEF had decreased significantly from 440 to $390 \mathrm{l} / \mathrm{min}$ after infusion of propranolol $2.1 \mathrm{mg}$, though the maximum fall in PEF occurred during or within five minutes of the end of the infusion. In nine of the subjects (six "responders" and three "nonresponders") the possibility that propranolol induced bronchoconstriction is due to blockade of mast cell $\beta$ receptors leading to increased mediator release was examined by measurement of plasma histamine concentration as an index of mast cell degranulation. There was no consistent change in plasma histamine concentration in either group. No evidence of increased mast cell mediator release has been found in association with propranolol induced bronchoconstriction.

Beta adrenoceptor antagonists, such as propranolol, are well known to carry the risk of increasing bronchoconstriction in asthmatic subjects, ${ }^{1}$ and fatal ${ }^{2}$ and near fatal cases continue to occur. ${ }^{34}$ The degree of airflow obstruction induced may be increased by other bronchoconstrictor influences, such as cold air, exercise ${ }^{5}$ or inhalation of methacholine ${ }^{6}$ or histamine. ${ }^{7}$ In normal subjects, however, $\beta$ blockers do not produce bronchoconstriction ${ }^{8}$ or increase airway reactivity. ${ }^{69}$ The reasons for this difference between asthmatic and normal individuals remain unclear. One possible explanation is that airway $\beta$ receptors may be under increased tonic drive in asthma; yet there is no convincing evidence of a functional innervation by sympathetic nerves of human airway smooth muscle 1011 and the circulating catecholamine concentrations are not raised in asthmatic patients under resting conditions. ${ }^{12}$ Reports of airway $\beta$ receptor responsiveness in asthmatics suggest that it is normal ${ }^{13}$ or may be reduced, ${ }^{14}$ but not increased. Mast cells in human lung also possess $\beta$ receptors. In vitro, $\beta$ agonists inhibit anaphylactic release of mediators including

Address for reprint requests: Dr PW Ind, Department of Clinical Pharmacology, Royal Postgraduate Medical School, London W12 0HS.

Accepted 14 June 1985 histamine, slow reacting substance of anaphylaxis, and prostaglandins ${ }^{15-17}$ and this action is antagonised by propranolol. ${ }^{18}$ In vivo, there is some evidence that endogenous plasma adrenaline may regulate mast cell mediator release in asthmatic subjects. ${ }^{19}$ The inhibition of propranolol induced bronchoconstriction by cromoglycate ${ }^{20}$ has been cited as evidence that mast cells play a part in the bronchoconstriction; but cromoglycate has other actions apart from mast cell stabilisation and it is therefore an unreliable probe of the mechanisms causing bronchoconstriction. $^{21}$

In the present study we have used plasma histamine measurements to investigate whether propranolol induced bronchoconstriction is associated with the release of mast cell mediators.

\section{Methods}

Fourteen well controlled asthmatic subjects (nine male) gave informed consent to the study, which was approved by the ethics committee of Hammersmith Hospital. None had suffered an exacerbation of wheeze or a respiratory infection in the preceding two months but all had previously shown, either spontaneously or after inhalation of salbutamol $200 \mu \mathrm{g}$, a greater than $20 \%$ improvement in $\mathrm{FEV}_{1}$. The mean 
age was 28 (range 19-36) years. All had more than two positive skinprick test responses to common allergens. All had mild asthma; the mean baseline FEV ${ }_{1}$ was 3.6 (range 2.6-5.01) 1. Mean vital capacity (VC) was 5.1 (range 3.6-7.61) 1 and mean peak expiratory flow (PEF) 463 (range 330-625) 1/min (table 1). Two of the subjects smoked (Nos 4 and 11). None of the subjects was receiving oral corticosteroid treatment and all treatment was withdrawn for a minimum of 12 hours before study. Subjects were studied at the same time of day after a light breakfast, having abstained from coffee, tea, and alcohol and from smoking for a minimum of 12 hours.

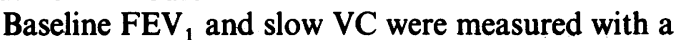
dry spirometer (Vitalograph) and PEF with a Wright peak flow meter as the best of three attempts. Two cannulas (Butterfly, Abbot 21G, and 19G) were inserted into a vein of each forearm. Solutions were infused by Braun pump at $1.8 \mathrm{ml} / \mathrm{min}$ through the smaller cannula and the larger sampling cannula was connected to a slowly running saline drip. Heart rate was continuously monitored (Hewlett Packard, Grass polygraph) and readings were obtained over a $30 \mathrm{sec}-$ ond recording. Supine blood pressure was determined indirectly automatically in duplicate by the Roche Arteriosonde 1217. PEF was measured after the subject had been tilted to $70^{\circ}$. PEF was recorded as being a simple, convenient, and reproducible index of lung function, reflecting clinically important changes in airflow obstruction.

Saline was infused over a control 30 minute period, during which baseline measurements and blood samples were obtained. Propranolol hydrochloride (dl racemic mixture) $10 \mathrm{mg}$ in $50 \mathrm{ml}$ saline was infused at $1.8 \mathrm{ml} / \mathrm{min}$ and followed by saline. Subjects were not aware of the start of propranolol infusion. Obser- vations and sampling were carried out at two to five minute intervals (being made more frequently when PEF was falling rapidly) over a total of 60 minutes unless a greater than $\mathbf{4 0 \%}$ fall in PEF occurred when the propranolol infusion was terminated (subjects 1 and 2). Finally, in 13 of the subjects standing PEF was repeated at 72 minutes before and 15 minutes after inhalation of salbutamol $200 \mu \mathrm{g}$.

Venous blood samples $(5 \mathrm{ml})$ were collected into chilled plastic tubes containing $1 \%(\mathrm{v} / \mathrm{v})$ ethylenediamine tetra-acetic acid (EDTA) $0.5 \mathrm{~mol} / \mathrm{l}, \mathrm{pH}$ 7.4, for histamine assay. After centrifugation (2000 $\mathrm{rev} / \mathrm{min}$ for 10 minutes) the top $1 \mathrm{ml}$ of plasma was carefully aspirated and stored at $-80^{\circ} \mathrm{C}$ until the assay was performed. The plasma histamine concentration was determined by a recently developed double isotope radioenzymatic assay. ${ }^{22}$ Sensitivity was $0.2 \mathrm{nmol} / 1$ and intra-assay and interassay coefficients of variation were $7 \%$ and $16.9 \%$ respectively. The normal range in our laboratory is $0.9-3.6 \mathrm{nmol} / 1$, which corresponds to that obtained by others using a totally different assay method. ${ }^{23}$

For ease of comparison between individuals mean values of PEF and plasma histamine were determined over periods of 10 minutes. The area under the curve (AUC) was calculated for change in PEF and plasma histamine against time according to the parallelogram rule, a computer program being used. Because it has been suggested that plasma histamine concentration is log normally distributed ${ }^{23}$ a non-parametric statistical test (the paired Wilcoxon signed rank test) was applied. Analysis of variance and paired and unpaired $t$ tests were also used in the analysis of the results. Predicted normal values for $\mathrm{FEV}_{1}$ in males, $\mathrm{FEV}_{1}$ in females, VC, and PEF were taken from Kory et al, ${ }^{24}$ Ferris et $a l,{ }^{25}$ Goldman and Becklake, ${ }^{26}$ and Cotes. ${ }^{27}$

Table 1 Effect of propranolol on peak expiratory flow rate (PEF): minimum PEF recorded during or within five minutes of termination of propranolol infusion

\begin{tabular}{|c|c|c|c|c|c|c|}
\hline \multirow[t]{2}{*}{ Subject No } & \multicolumn{3}{|c|}{ Initial } & \multirow{2}{*}{$\begin{array}{l}\text { Propranolol } \\
\text { dose }(\mathrm{mg} / \mathrm{kg})\end{array}$} & \multicolumn{2}{|c|}{ Maximum fall in PEF } \\
\hline & $\begin{array}{l}\overline{F E V_{1}} \\
(\% p p\end{array}$ & $\left.s^{23-26}\right)$ & $P E F$ & & $(l / \min )$ & $(\%$ baseline $)$ \\
\hline $\begin{array}{l}1 \\
2 \\
3 \\
4 \\
5 \\
6 \\
7 \\
8 \\
9 \\
10 \\
11 \\
12 \\
13 \\
14 \\
\text { Mean } \\
\text { SD }\end{array}$ & $\begin{array}{r}77 \\
84 \\
114 \\
79 \\
84 \\
86 \\
88 \\
119 \\
88 \\
88 \\
93 \\
105 \\
102 \\
104 \\
94 \\
13\end{array}$ & $\begin{array}{r}87 \\
100 \\
146 \\
95 \\
112 \\
99 \\
88 \\
113 \\
122 \\
112 \\
121 \\
104 \\
103 \\
129 \\
109 \\
16\end{array}$ & $\begin{array}{r}77 \\
70 \\
83 \\
85 \\
86 \\
85 \\
83 \\
97 \\
68 \\
72 \\
84 \\
102 \\
85 \\
81 \\
83 \\
9\end{array}$ & $\begin{array}{l}0.134 \\
0.083 \\
0.130 \\
0.159 \\
0.142 \\
0.171 \\
0.159 \\
0.129 \\
0.144 \\
0.163 \\
0.141 \\
0.136 \\
0.164 \\
0.139 \\
0.142 \\
0.022\end{array}$ & $\begin{array}{r}235 \\
156 \\
195 \\
95 \\
151 \\
105 \\
84 \\
102 \\
79 \\
49 \\
44 \\
34 \\
17 \\
20 \\
92 \\
68\end{array}$ & $\begin{array}{r}51 \\
50 \\
39 \\
32 \\
30 \\
26 \\
20 \\
17 \\
17 \\
12 \\
10 \\
6 \\
5 \\
4 \\
23 \\
16\end{array}$ \\
\hline
\end{tabular}




\section{Results}

A variable fall in PEF occurred during or within five minutes of stopping the propranolol infusion (table 1). In two subjects (Nos 1 and 2) large falls in PEF occurred and the propranolol infusion was stopped after 7.4 and $6.4 \mathrm{mg}$ had been given. Subject 2 was treated with incremental isoprenaline infusions and subject 1 followed the protocol. Both recovered uneventfully. Arbitrarily we decided to classify subjects with a maximum fall in PEF on any single reading greater than $15 \%$ of baseline as "responders" (Nos 1-9) and those with less than 15\% maximum fall as "non-responders" (Nos 10-14). There was no correlation between maximum fall in PEF and baseline $\mathrm{FEV}_{1}, \mathrm{VC}$, and PEF ( $\mathrm{r}=0.45,0.24$, and 0.32 ; NS). The time course of the mean PEF and heart rate response to propranolol is shown in figure 1 . In "responders" a significant fall in mean (SE) PEF from the baseline 440 (31) to $390(33) \mathrm{l} / \mathrm{min}$ (p < 0.005) had occurred by six minutes after $2.1 \mathrm{mg}$ propranolol had been infused. At this time the supine heart rate had also fallen significantly from 70 (3.4) to 65 (3.2) beats $/ \min (\mathrm{p}<0.0005)$ despite tilting manoeuvres.
Figure 2 shows the individual changes in PEF and plasma histamine for the nine subjects in whom both were measured. Baseline plasma histamine concentrations were within the range recorded in normal subjects with the exception of that of sutject 11. This subject's baseline lung function was no worse than that of the others (table 1). There was no significant correlation between baseline $\mathrm{FEV}_{1}, \mathrm{VC}$, or PEF and baseline plasma histamine concentration. ${ }^{12}$ The variability of baseline plasma histamine is shown with a mean coefficient of variation of $31 \%$.

There was no consistent change in plasma histamine during the bronchoconstrictor response after propranolol infusion. Mean (SE) PEF fell by a maximum of $122(17) \mathrm{l} / \mathrm{min}(27 \%(3.3 \%)$ baseline) in the six "responders" and by $32(8) \mathrm{l} / \mathrm{min}(7 \%(1.5 \%)$ baseline) in the three "non-responders" (table 1). Mean plasma histamine concentration did not change significantly in either group (fig 3). There was no significant correlation between baseline plasma histamine and either maximum fall in PEF or the area under the curve for change in PEF with time. There was also no significant correlation between maximum fall in PEF and maximum rise in plasma histamine

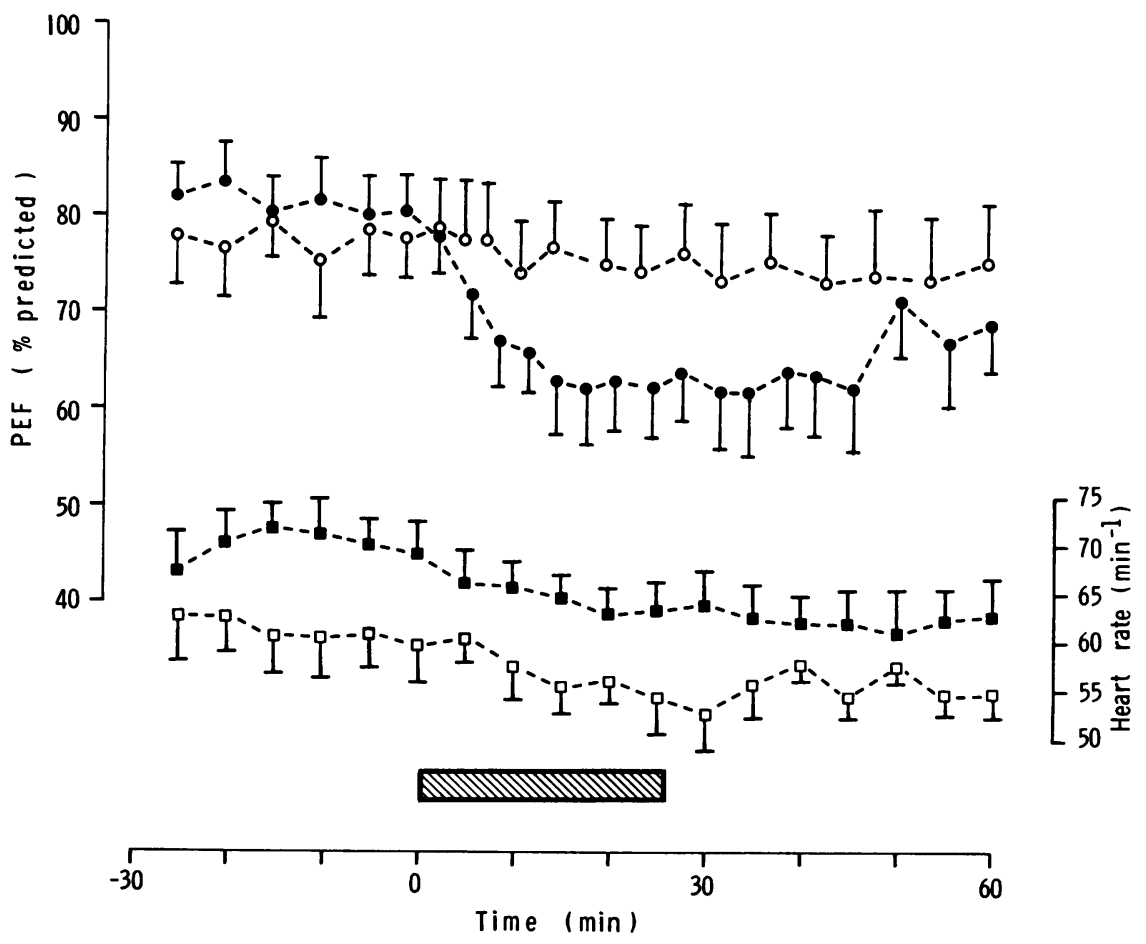

Fig 1 Time course of effect of propranolol infusion on peak expiratory flow (PEF) (percentage of predicted values) and heart rate (beats/min) (mean and $S E$ ) in 14 asthmatic subjects. Closed circles represent nine "responders" and open circles five "non-responders." 

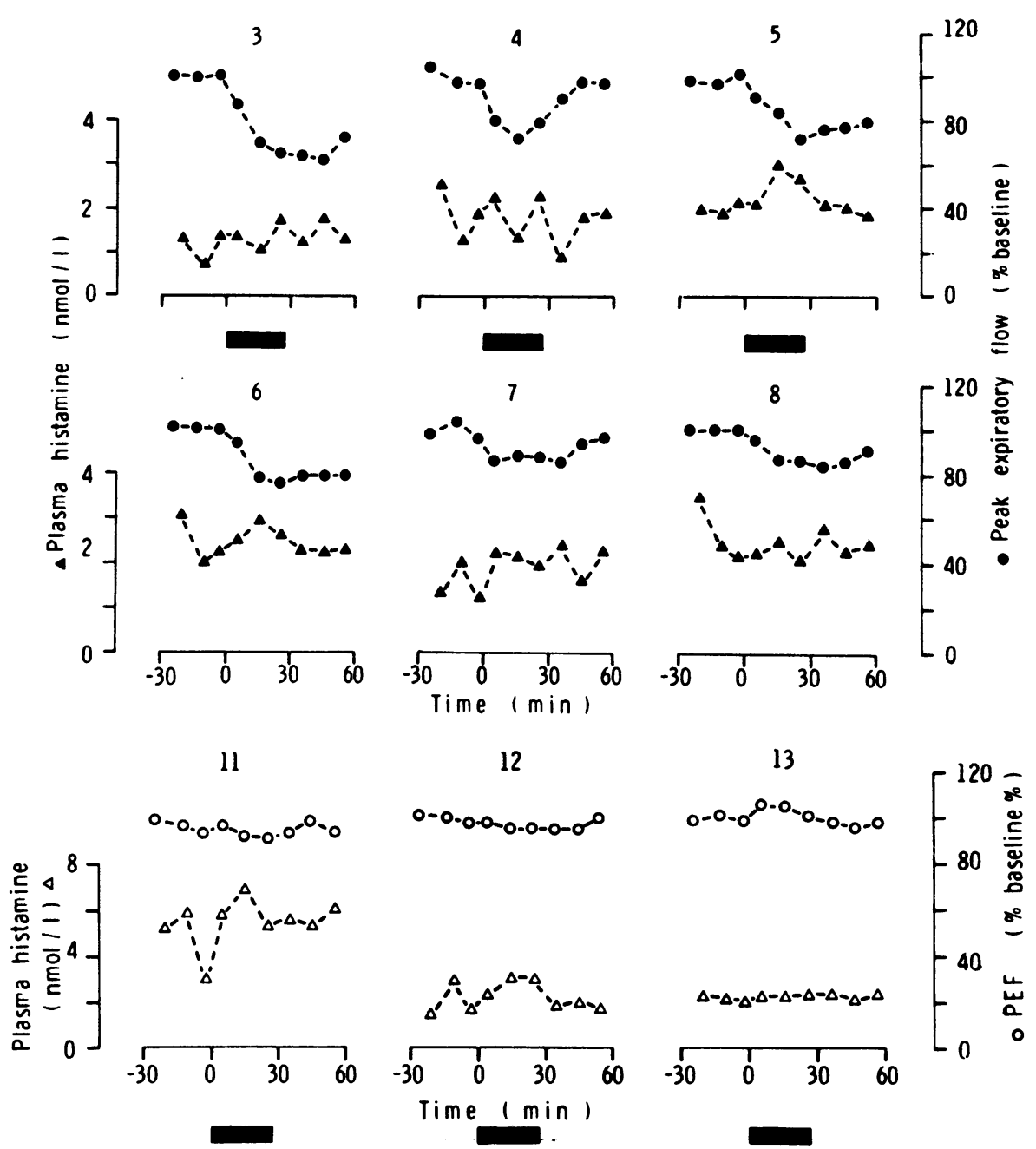

Fig 2 Change in plasma histamine (nmolll) and peak expiratory flow (PEF) (percentage of baseline) with time before and after propranolol infusion in nine asthmatic subjects. Closed symbols represent "responders" and open symbols "non-responders." Conversion: SI to traditional units-Histamine: $1 \mathrm{nmol} / \mathrm{l}=0.11 \mathrm{ng} / \mathrm{ml}$.

concentration, or between the area under the curve for change in PEF with time and plasma histamine with time.

Baseline heart rate and systolic blood pressure were higher in "responders" than in "non-responders," though this trend did not achieve significance (table 2). Propranolol caused a reduction in heart rate in both groups and a reduction in systolic blood pressure in "responders" (table 2).

PEF increased by $16 \%(5 \%)(\mathrm{p}<0.01) 15$ minutes after salbutamol (35 minutes after propranolol) in the "responders" and by 5\% (1\%) (p < 0.05$)$ in the "non-responders." This difference was significant (p
$<0.05)$. The final PEF was not different in the two groups.

\section{Discussion}

Propranolol administered intravenously in a dose known to produce $\beta$ receptor blockade ${ }^{28}$ (which here produced heart rate slowing and a decrease in systolic blood pressure) produced a significant fall in PEF in nine out of 14 subjects with atopic asthma studied under identical conditions. These "responders" were not distinguishable from "non-responders" by their baseline pulmonary function or by any other clinical 


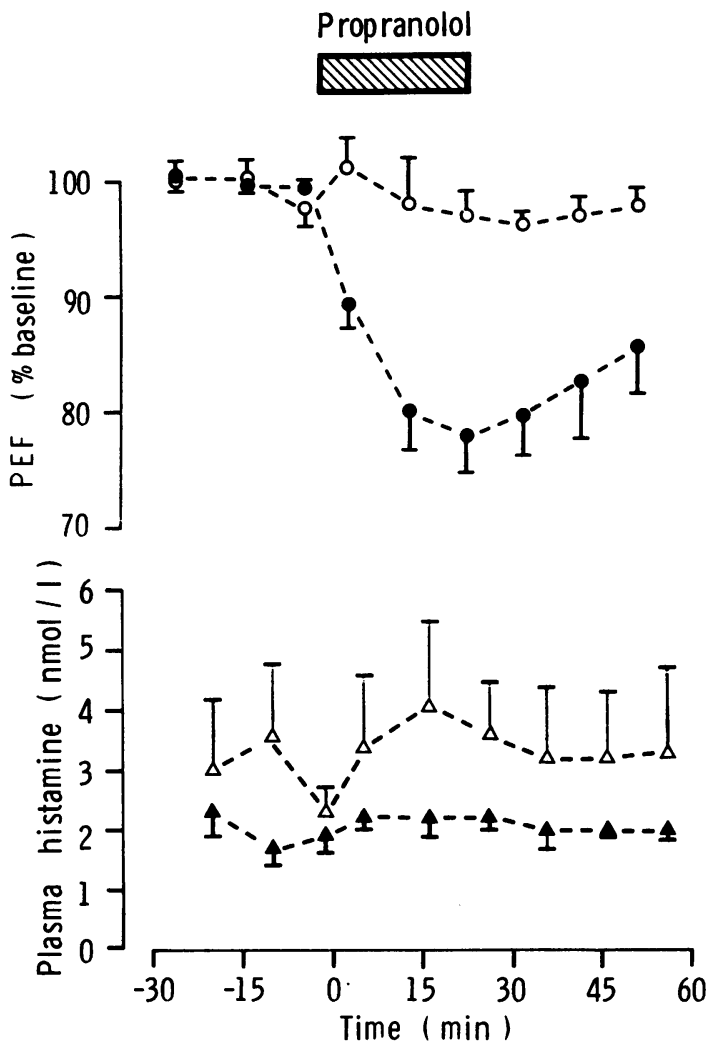

Fig 3 Mean change in plasma histamine (nmol/l) and peak expiratory flow (PEF) (percentage of baseline) with time before and after propranolol infusion (hatched bar) in nine asthmatic subjects. Closed symbols represent six "responders" and open symbols three "non-responders." Conversion: SI to traditional units-Histamine: $1 \mathrm{nmol} / \mathrm{l}=$ $0.11 \mathrm{ng} / \mathrm{ml}$.

characteristics, as has previously been reported. ${ }^{29}$ It has been suggested that non-specific bronchial reactivity may correlate with response to inhaled propranolol, ${ }^{30}$ but this was not measured in the present study. "Responders" did, however, have higher systolic blood pressure and heart rate than "non- responders," although the difference did not achieve statistical significance. These findings raise the possibility of an increased "sympathetic drive" in these patients. In a similar group of subjects with mild asthma plasma adrenaline and noradrenaline concentrations at rest were normal and, in the absence of a significant sympathetic innervation of bronchial smooth muscle, it remains unclear what chronic stimulus of $\beta$ receptors is antagonised by propranolol. After the start of propranolol infusion the time course of bronchoconstriction appeared to parallel the reduction in heart rate (fig 1), but there were too few time points to assess this by formal statistical analysis. This contrasts with recent findings in guinea pigs and rats, where propranolol induced bronchoconstriction appears to be independent of airway $\beta$ receptor blockade. $^{31}$ The bronchodilatation produced by salbutamol is consistent with the relatively short duration of action of intravenous propranolol and the high concentration of inhaled $\beta$ agonist at airway smooth muscle $\beta$ receptors.

In eight of the nine of the subjects (six "responders" and two "non-responders") in whom plasma histamine was measured baseline concentrations were normal, which is consistent with previous findings in patients with asthma. ${ }^{32}$ There was no consistent change in plasma histamine concentrations after propranolol. Many studies have used plasma histamine concentration as an index of mast cell degranulation in vivo. ${ }^{32} \mathrm{~A}$ small but significant increase in plasma histamine was seen when a similar degree of bronchoconstriction was caused by antigen challenge. ${ }^{22}$ One conclusion from the present study might therefore be that propranolol induced bronchoconstriction, in contrast to antigen challenge, is not a mast cell mediated phenomenon. Since we started the study, however, we have been increasingly concerned that the major source of circulating histamine is basophils, and these cells lack a functional $\beta$ adrenoceptor. Changes in plasma histamine could therefore be due to inappropriate sample handling, to changes in basophil count, and, most interestingly, to increased basophil "releasability". ${ }^{33}$ So we cannot

Table 2 Effect of propranolol on heart rate and systolic blood pressure (SBP) in "responders" and "non-responders"

\begin{tabular}{|c|c|c|c|c|}
\hline & \multicolumn{2}{|l|}{ Baseline* } & \multicolumn{2}{|l|}{ After propranolol $\uparrow$} \\
\hline & $\begin{array}{l}\text { Heart rate } \\
\text { (beats/min) }\end{array}$ & $\begin{array}{l}S B P \\
(m m \mathrm{Hg})\end{array}$ & $\begin{array}{l}\text { Heart rate } \\
\text { (beats/min) }\end{array}$ & $\begin{array}{l}S B P \\
(\mathrm{~mm} \mathrm{Hg})\end{array}$ \\
\hline $\begin{array}{l}\text { Responders } \\
\text { Non-responders } \\
\text { Comparison of responders and }\end{array}$ & $\begin{array}{l}70(3.3) \\
60(3.9)\end{array}$ & $\begin{array}{l}120(3.3) \\
112(2.3)\end{array}$ & $\begin{array}{l}62(3.2)(\mathrm{p}<0.001) \\
54(2.4)(\mathrm{p}=0.01)\end{array}$ & $\begin{array}{l}111(5.3)(\mathrm{p}<0.005) \\
111(3.9)(\mathrm{NS})\end{array}$ \\
\hline non-responders & $p=0.08$ & $p=0.08$ & $p=0.08$ & NS \\
\hline
\end{tabular}

*Mean (SE) values for four heart rate and blood pressure recordings at five minute intervals during saline infusion after more than 15 minutes rest in nine "responders" and five "non-responders."

†Mean (SE) values for seven heart rate and two blood pressure measurements 30-60 minutes after the start of propranolol infusion in eight

"responders" and five "non-responders" (subject 2 omitted). P values refer to comparison with baseline values. 
entirely exclude the possiblity that the negative findings in our in vivo study, in contrast to the positive results with $\beta$ agonists and antagonists on mast cells in vitro, may simply reflect the absence of a functional $\beta$ adrenoceptor on human basophils. ${ }^{34}$ Because exogenous histamine is cleared so efficiently ${ }^{35}$ local pulmonary mast cell histamine release is not excluded by the failure to detect a rise in circulating histamine, and it has been suggested recently that asthmatic subjects showing increased non-specific hyperreactivity (as "responders" might be expected to do) tend to release less histamine in response to antigen bronchoprovocation. ${ }^{36}$ Further study of $\beta$ receptor antagonism of mast cell mediator release using a more sensitive and specific marker would be of interest.

We conclude that bronchoconstriction induced by a $\beta$ receptor antagonist is not associated with an increase in plasma histamine concentration, but that this does not exclude an action on mast cells because of the limitations of plasma histamine concentration as an index of mast cell degranulation.

This work was supported by a Medical Research Council programme grant.

\section{References}

1 McNeill RS. Effect of a $\beta$-adrenergic-blocking agent, propranolol, on asthmatics. Lancet 1964;ii:1101-2.

2 Cauld DR, Pain MCF, Rubinfield AR. Beta-blocking drugs and airways obstruction. Med J Aust 1979;ii:88.

3 Raine JM, Palazzo MG, Kerr JH, Sleight P. Near-fatal bronchospasm after oral nadolol in a young asthmatic and response to ventilation with halothane. $\mathrm{Br} \mathrm{Med} J$ 1981;282:548-9.

4 Williams IP, Millard FJC. Severe asthma after inadvertent ingestion of oxprenolol. Thorax 1980;35:160.

5 Schwartz S, Davies S, Juers JA. Life-threatening cold and exercise-induced asthma potentiated by administration of propranolol. Chest 1980;78:100-1.

6 Zaid G, Beall GN. Bronchial response to beta-adrenergic blockade. N Engl J Med 1966;275:590-4.

7 Bouhuys A, Douglas JC, Euyatt AR. Pharmacological modification of histamine-mediated airway responses (abstract). J Clin Invest 1971;50:9-10A.

8 Tattersfield AE, Leaver DG, Pride NB. Effects of beta adrenergic blockade and stimulation of normal human airways. J Appl Physiol 1973;35:613-9.

9 Townley RE, McGeady S, Bewtra A. The effect of beta adrenergic blockade on bronchial sensitivity to acetylbeta-methacholine in normal and allergic rhinitis subjects. J Allergy Clin Immunol 1976;57:358-66.

10 Richardson JB. Nerve supply to the lungs. Am Rev Respir Dis 1979;119:785-802.

11 Ind PW, Scriven AJI, Dollery CT. Use of tryramine to probe pulmonary noradrenaline release in asthma. Clin Sci 1983;64:9P.

12 Barnes PJ, Ind PW, Brown MJ. Plasma histamine and catecholamines in stable asthmatic subjects. Clin Sci
1982;62:661-5.

13 Harvey JE, Baldwin CJ, Wood PJ, Alberti KGMM, Tattersfield AE. Airway and metabolic responsiveness to intravenous salbutamol in asthma: effect of regular inhaled salbutamol. Clin Sci 1981;60:579-85.

14 Barnes PJ, Pride NB. Dose-response curves to inhaled beta-adrenergic agonists in normal and asthmatic subjects. Br J Clin Pharmacol 1983;15:677-82.

15 Assem ESK, Schild HO. Inhibition by sympathomimetic amines of histamine release induced by antigen in passively sensitized human lung. Nature 1969;224:1028-9.

16 Orange RP, Kaliner MA, Laraia PJ, Austen KF. Immunological release of histamine and slow reacting substance of anaphylaxis from human lung. II. Influence of cellular levels of cyclic AMP. Fed Proc 1971;30:1725-9.

17 Strandberg K, Mathe AA, Yen SS. Release of histamine and formation of prostaglandins in human lung tissue and rat mast cells. Int Arch Allergy Appl Immunol 1977;53:520-9.

18 Assem EKS, Schild HO. Antagonism by $\beta$-adrenoceptor blocking agents of the anti-anaphylactic effect of isoprenaline. Br J Pharmacol 1971;42:620-30.

19 Barnes P, FitzGerald G, Brown M, Dollery C. Nocturnal asthma and changes in circulating epinephrine, histamine and cortisol. $N$ Engl J Med 1980;303:263-7.

20 Koeter GH, Meurs H, Manchy JGR, de Vries K. Protective effect of disodium cromoglycate on propranolol challenge. Allergy 1982;37:587-90.

21 Altounyan REC. Review of the clinical activity and modes of action of sodium cromoglycate. In: Pepys J, Edwards AM, eds. The mast cell: its role in health and disease. Bath: Pitman Medical, 1979:1199-216.

22 Brown MJ, Ind PW, Causon R, Lee TH. A novel doubleisotope technique for the enzymatic assay of plasma histamine: application to estimation of mast cell activation assessed by antigen challenge in asthmatics. $J$ Allergy Clin Immunol 1982;69:20-4.

23 Lorenz W, Doenicke A, Schoning B, Neugebauer E. The role of histamine in adverse reactions to intravenous agents. In: Thornton JA, ed. Adverse reactions of anaesthetic drugs. Amsterdam: Elsevier/North Holland: Biomedical Press, 1981:169-238.

24 Kory RC, Callahan R, Boren HG, Syner JC. The Veterans Administration-Army cooperative study of pulmonary function. I. Clinical spirometry in normal men. Am J Med 1961;30:243-58.

25 Ferris BG jun, Anderson DO, Zickmantel R. Prediction values for screening tests of pulmonary function. Am Rev Respir Dis 1965;91:252-61.

26 Goldman HI, Becklake MR. Respiratory function tests. Am Rev Tuberc Pulm Dis 1959;79:457-67.

27 Cotes JE. Lung function: assessment and application in medicine. 4th ed. Oxford: Blackwell Scientific Publications, 1979

28 Coltart DJ, Shand DG. Plasma propranolol levels in the quantitative assessment of $\boldsymbol{\beta}$-adrenergic blockade in man. Br Med J 1970;iii:731-4.

29 Gayrard P, Orehek J, Grimaud C, Charpin J. Betaadrenergic function in airways of healthy and asthmatic subjects. Thorax 1975;30:657-62.

30 Ruffin RE, Frith MB, Anderton RC, Kumana CR, Newhouse MT, Hargreave FE. Selectivity of beta adrenoceptor antagonist drugs assessed by histamine bronchial provocation. Clin Pharmacol Ther 1979;25:536-40.

31 Maclagan J, Ney U. Investigation of the mechanism of propranolol-induced bronchoconstriction. Br J Pharma- 
col 1979;66:409-18.

32 Ind PW, Barnes PJ, Brown MJ, Causon R, Dollery CT. Measurement of plasma histamine in asthma. Clin Allergy 1983;13:61-7.

33 Findlay SR, Lichtenstein LM. Basophil "releasability" in patients with asthma. Am Rev Respir Dis 1980;122:53-9.

34 Lichtenstein LM, Margolis S. Histamine release in vitro: inhibition by catecholamines and methylxanthines. Sci- ence 1968;161:902-3.

35 Ind PW, Brown MJ, Lhoste FJM, Macquin IM, Dollery CT. Concentration effect relationships of infused histamine in normal volunteers. Agents Actions 1982;12:12-5.

36 Howarth PH, Pao GJK, Durham SR, Lee TH, Kay AB, Holgate ST. Influence of airway reactivity on circulating histamine and neutrophil chemotactic activity (abstract). Thorax 1983;38:705.

\section{Book notices}

High Frequency Ventilation in Intensive Care and During Surgery. Ed Graziano C Carlon and William S Howland. (Pp 304; \$59.75.) Marcell Dekker, 1985.

A comprehensive and up to date review of the rapidly developing field of high frequency ventilation (HFV) is much needed. This volume of Lung Biology in Health and Disease (No 26) reflects developments in both Europe and the United States, with a contribution from Australia. The references are prolific and current, some less than a year old. The editors have attempted to delineate the three methods of HFV-high frequency pressure ventilation (HFPPV), high frequency jet ventilation (HFJV), and high frequency oscillation (HFO) - by allocating chapters according to appropriate authors. This is a mistake and has resulted in extensive and annoying repetition. Not only do the introductory chapters describe the uses of HFV, but there are separate chapters on application of HFPPV, HFJV, and HFO. As the proposed uses of each differ so little one comprehensive chapter would have sufficed. Similar criticism can be directed at the sections on the physiological effects of each technique. The first two chapters provide an introduction that pre-empts many of the conclusions of later chapters. One wonders whether or not it is deliberate that all the paragraphs on page 2 begin with the words "high frequency" Unfortunately in chapter 3 new terms and abbreviations are introduced with inadequate explanation. This chapter is a collage of complicated research work and theory from two groups of authors, with a concluding paragraph by the editors. Its attempt to provide an explanation of the mechanisms of gas transport in HFV left me floundering and I was relieved by the conclusion that "No definitive solution ... is offered." As we read there is a continuing sense of déjà vu. By the time I reached page 64 with the third repeat of both the definition of HFV and the characteristics of HFPPV, I was becoming decidedly irritated. While it is important for chapters in such a book to stand on their own it must be doubted whether the editors bothered to read the text. The intrusion of a list of up to eight names with dates does not make for easy reading. While the book will be a useful reference work for those concerned with the clinical and research applications of HFV, it cannot be recommended for widespread purchase. It might be worth borrowing from the library to test the assertion by one contributor that "In the minds of some, high frequency ventilation is still a technique in search of an application."-RBH

YAG Laser Bronchoscopy (Surgical Science Series, vol 5). JF Dumon. (Pp 116; £31.25.) Praeger Publishers, 1985.

JF Dumon is well known as one of the most experienced exponents of bronchoscopic treatment with the neodymium YAG laser. This short book describes his own technique with a modified Wolf rigid bronchoscope and a closed circuit system for general anaesthesia with the patient breathing spontaneously. Extra channels have been fitted to the bronchoscope for the laser and suction tube. The book is well illustrated with line drawings and some black and white endoscopic photographs. It contains some useful practical points. The importance of haemorrhage and hypoxaemia as complications is well recognised and manoeuvres for controlling them are well described. A preliminary chapter emphasises the importance of the anatomical relationships of the trachea, major bronchi, and major blood vessels. The anaesthetic technique is somewhat briefly described. The book is well referenced, apart from omission of British publications. While most workers using a laser might agree with the author's recommendation to use a rigid bronchoscope and general anaesthesia, the book gives a narrow view of the subject. Alternative techniques such as anaesthesia by jet ventilation and use of the fibreoptic bronchoscope are dismissed in a sentence or two without discussion to support these views. Further chapters discuss the indications for laser treatment in both tumours and benign lesions but the author's clinical series, although large, are somewhat anecdotally described. There is considerable repetition, particularly in a long concluding chapter which adds little to the preceding chapters. In conclusion, this book is likely to interest only those with a serious intention of using a laser themselves. The clinician in search of a balanced and comprehensive account of lasers in pulmonary medicine and surgery will not achieve much from reading this book alone.-MRH 